\title{
Creating New Stories: The Role of Evaluation in Truth and Reconciliation
}

\author{
Larry Bremner \\ Proactive Information Services Inc.
}

\begin{abstract}
This paper describes the origins of the Truth and Reconciliation Commission of Canada, with the focus on how evaluators and their professional associations can contribute to truth and reconciliation. At the professional association level, the actions that the Canadian Evaluation Society has taken in committing itself to incorporating truth and reconciliation into its values, principles, and practices are highlighted. At the individual level, evaluators are challenged to reflect on their practice. As storytellers, evaluators have been complicit in telling stories that, while highlighting the damaging legacy of residential schools, have had little influence on changing the status quo for Indigenous peoples and communities. The need to reconsider who should be telling the stories and what stories should be told are critical issues upon which evaluators must reflect. The way forward also needs to include a move toward a more holistic view, incorporating the interaction between human and natural systems, thus better reflecting an Indigenous, rather than a Western, worldview. The imperative for evaluators, both in Canada and globally, to see Indigenous peoples "as creators of their own destinies and experts in their own realities" is essential if evaluation is to become "a source of enrichment ... and not a source of depletion or denigration."
\end{abstract}

Keywords: competency domains, Indigenous approaches, reconciliation, relationality, residential schools, storytelling, Tribal Critical Theory, truth

Résumé : Cet article décrit les origines de la Commission de vérité et réconciliation du Canada, en mettant l'accent sur la façon dont les évaluateurs et évaluatrices et leurs associations professionnelles peuvent contribuer à la vérité et à la réconciliation. Il est notamment question des actions que la Société canadienne dévaluation a posées en séngageant à inclure la vérité et la réconciliation dans ses valeurs, ses principes et ses pratiques. Au niveau individuel, les évaluateurs et les évaluatrices sont invité.e.s à réfléchir à leur pratique. Comme conteurs et conteuses, les évaluateurs et évaluatrices ont été complices en racontant des histoires qui, tout en soulignant l'héritage néfaste des pensionnats, ont eu peu d'influence sur le changement du statu quo des peuples et communautés autochtones. Il est d'une importance critique que les évaluateurs et évaluatrices réfléchissent à qui devrait raconter les histoires et quelles histoires devraient être racontées. Pour aller de l'avant, il faudra adopter une approche holistique, qui incorpore l'interaction entre l'humain et les systèmes

Corresponding author: Larry Bremner, P.O. Box 439, Sandy Hook, MB, R0C 2W0; larry@ proactive.mb.ca

๑) 2019 Canadian Journal of Program Evaluation / La Revue canadienne d'évaluation de programme 34.2 (Fall / automne), 331-342 doi: 10.3138/cjpe.67976 
naturels, reflétant ainsi davantage un point de vue autochtone plutôt qu'occidental. Il sera impératif pour les évaluateurs et évaluatrices, autant au Canada qu'ailleurs dans le monde, de voir les peuples autochtones comme des "créateurs de leur propre destinée et experts de leur propre réalité» si lévaluation espère devenir "une source denrichissement... et non une source d'appauvrissement et de dénigrement.»

Mots clé: domaines de compétence, approches autochtones, réconciliation, relationnel, pensionnats, récits, théorie critique tribale, vérité

[Larry Bremner is a Métis man whose great-grandmother Rose Boucher was born in 1867 in St. Francis Xavier, Manitoba. She moved with her parents by ox team to St. Louis, Saskatchewan, in 1882. In 1883, she married Moise Bremner. On November 19, 1883, Moise, his father, William, and 28 other Métis signed a petition protesting the 1883 Order in Council transferring the Métis lands at St. Louis to the Prince Albert Colonization Company; the petition was ignored by the Canadian government. Moise was a member of Captain Baptiste Boucher's company, one of the 19 dizaines (groups of 10 people) led by Gabriel Dumont during the 1885 Métis Resistance. After the resistance at Batoche, the family moved to the United States and returned to what is now Saskatchewan after the Canadian government granted amnesty. They homesteaded in Domremy, Saskatchewan, in 1905.]

\section{INDIAN RESIDENTIAL SCHOOLS IN CANADA}

In Canada, residential schools operated until the late 1990s under the auspices of the Government of Canada in partnership with a variety of churches, which included the Roman Catholic, Anglican, United, Methodist, and Presbyterian churches. The first residential school opened in Alderville, Ontario, in 1849, with the last residential school operated by the Canadian government, the Gordon Indian Residential School in Saskatchewan, closing in 1996. It is estimated that over 150,000 Indian, Métis, and Inuit students attended these schools. Many of the children lived in poor conditions and were often sexually and physically abused. Residential schools included "industrial schools, boarding schools, homes for students, hostels, billets, residential schools, residential schools with a majority of day students, or a combination of any of the above. At the request of Survivors, this definition has evolved to include convents, day schools, missions, sanatoriums and settlement camps" (Legacy of Hope Foundation, 2014, p. 3).

Residential schools were intended to assimilate Indigenous peoples into the mainstream dominant culture. Children were forcibly removed from their families, isolated from their homes and communities, and not allowed to speak their language or engage in their culture or traditions, "based on the assumption Aboriginal cultures and spiritual beliefs were inferior and unequal. Indeed, some sought, as it was infamously said, 'to kill the Indian in the child"' (IndigenousFoundations.arts.bc.ca, 2009). The establishment and operation of residential schools in Canada was a vital element in Canada's approach to Indigenous peoples, an approach that has been described as "cultural genocide": 
Cultural genocide is the destruction of those structures and practices that allow the group to continue as a group. States that engage in cultural genocide set out to destroy the political and social institutions of the targeted group. Land is seized, and populations are forcibly transferred and their movement is restricted. Languages are banned. Spiritual leaders are persecuted, spiritual practices are forbidden, and objects of spiritual value are confiscated and destroyed. And, most significantly to the issue at hand, families are disrupted to prevent the transmission of cultural values and identity from one generation to the next.

In its dealing with Aboriginal people, Canada did all these things. (TRC, 2015)

In May 2006, the Indian Residential School Settlement Agreement was approved by all federal political parties. This agreement was seen as an important step in helping to heal the harm caused by the residential school legacy.

The Settlement Agreement represents the consensus reached between legal counsel for former students, legal counsel for the Churches, the Assembly of First Nations, other Aboriginal organizations and the Government of Canada. The implementation of this historic agreement brings a fair and lasting resolution to the legacy of Indian Residential Schools. (Indian and Northern Affairs Canada, n.d.)

\section{THE TRUTH AND RECONCILIATION COMMISSION OF CANADA}

Article Seven of the Indian Residential School Agreement called for the establishment of a Truth and Reconciliation Commission. The Truth and Reconciliation Commission of Canada (TRC) was officially launched in 2008. The original Commissioners resigned and the three new Commissioners were appointed: Justice Murray Sinclair, an Ojibwa judge from the court of the Queen's Bench, Manitoba; lawyer Chief Wilton Littlechild from Maskwacis (Hobbema), Alberta; and Marie Wilson, a Canadian Broadcasting Corporation broadcaster from Yellowknife, Northwest Territories. They were officially recognized in a ceremony that took place in July 2009. As noted in the Truth and Reconciliation Commission of Canada Interim Report (2012), the mandate was to "reveal the complete story of Canada's residential school system, and lead the way to respect through reconciliation ... for the child taken, for the parent left behind."

Between 2010 and 2014, the Commission held seven national events. Over 9,000 residential school survivors registered to attend these events, and it is presumed that more attended than registered. Furthermore, it is estimated that over 155,000 individuals attended the national events. In addition, regional events and "town halls" were organized, as well as 238 local hearings in 77 communities across Canada:

Until the Commission was established, the voices of those who were most directly affected by the residential school experience, particularly the former students, had largely been missing from the historical record. The Commission made a commitment to offer everyone involved with the residential school system the opportunity to speak about 
their experience. The Commission received over 6,750 statements from Survivors of residential schools, members of their families, and other individuals who wished to share their knowledge of the residential school system and its legacy. (TRC, 2015)

The impact of residential schools has been transferred from grandparents to parents to children, resulting in intergenerational trauma. There are approximately 80,000 residential school survivors still living, so, for many, their stories still need to be heard.

In December 2015, the Truth and Reconciliation Commission of Canada released its Final Report, which included 94 Calls to Action. Many of the Calls to Action, which focus on child welfare, education, health, and justice, call for regular monitoring and evaluation. In addition, the Parliament of Canada was urged to enact a National Council for Reconciliation, with a mandate that was to include the following:

i. Monitor, evaluate, and report annually to Parliament and the people of Canada on the Government of Canada's post-apology progress on reconciliation to ensure that government accountability for reconciling the relationship between Aboriginal peoples and the Crown is maintained in the coming years.

ii. Monitor, evaluate, and report to Parliament and the people of Canada on reconciliation progress across all levels and sectors of Canadian society, including the implementation of the Truth and Reconciliation Commission of Canada's Calls to Action. (TRC, 2015)

\section{THE CANADIAN EVALUATION SOCIETY'S RESPONSE TO THE TRC}

The Calls to Action hold major implications for all Canadians, including evaluators, and the roles we can play in the process of truth and reconciliation. The Canadian Evaluation Society (CES), the organization representing evaluators in Canada, has taken a few first steps in an attempt to address reconciliation. The CES is committed to incorporating reconciliation in its values, principles, and practices. In May 2016, the Diversity Working Group put forward the following resolutions, which were adopted by the CES National Board at its May 4, 2016, meeting:

Resolved, That the notion of reconciliation be included in the existing CES value of inclusiveness and that the CES make a public statement to that effect,

Resolved, That, as part of its next competency scheme review, the CES include reconciliation explicitly,

Resolved, That the CES strengthen its promotion of and support for culturally responsive evaluation, and 
Resolved, That the Diversity Working Group supports the CES in implementing consideration for reconciliation in its activities. (CES, 2016a)

The Diversity Working Group was established in 2008 to advise the CES Board on issues relating to diversity and inclusion within CES and to promote inclusive evaluation practice within the evaluation community.

As the initial step in addressing the first resolution, in June 2016 the CES National President sent a letter to the Minister of Indigenous and Northern Affairs Canada, outlining the resolutions, and stated that "CES will be actively pursuing actions to include these values in its strategies, plans, and activities" (CES, 2016b). The Prime Minister was copied. Other public statements regarding the resolutions and CES's intent to address reconciliation have been made in presentations at CES and AEA conferences. Furthermore, as evidenced in the recent national conferences, CES has attempted to increase the profile and understanding of Indigenous perspectives as part of its conferences.

Evidence of CES addressing the second resolution can be found in the new competencies that resulted from the CES Credential Competency Review, which included Indigenous input and feedback. There are five competency domains, with multiple competencies within each domain: Reflective Practice, Technical Practice, Situational Practice, Management Practice, and Interpersonal Practice. As part of the competency review process, a number of the original competencies were revised and some new competencies were added. The following are examples of a new and a revised competency that appear under the Situational Practice Domain to address specifically the CES motion regarding the TRC. The Situational Practice Domain comprises competencies that are to "focus on understanding, analyzing, and attending to the many circumstances that make every evaluation unique, including culture, stakeholders, and context."

New: Uses evaluation processes and practices that support reconciliation and build stronger relationships among Indigenous and non-Indigenous peoples.

Previous: Shares evaluation expertise

Revised: Engages in reciprocal processes in which evaluation knowledge and expertise are shared between the evaluator and stakeholders to enhance evaluation capacity for all. (CES, n.d.)

The CES's Essential Skills Series (ESS) is a series of entry-level courses developed by CES. The series is four days/20 hours in length and is intended to help participants gain basic levels of knowledge, skill, and appreciation with respect to the essential elements of evaluation. Upon completion, it is hoped that participants will be able to enter and participate in evaluation and develop as evaluation professionals. The Essential Skills Series has also undergone revisions. A Diversity Working Group Co-Chair, in partnership with the Mi'kmaw Native Friendship Centre, the Canadian Evaluation Society, and the Nova Scotia Health Research 
Foundation used this as an opportunity to adapt the ESS to include Indigenous knowledge and culture. This initiative also included a day of reflection during which there was a discussion of which content and delivery methods could make ESS more culturally responsive. The feedback has been provided to the Board for incorporation into the next round of ESS revisions.

Another initiative that CES is supporting in its efforts in reconciliation is at the global level. It supports a Global Network called EvalIndigenous, of which I am the co-chair. EvalIndigenous is attempting to

Advance the recognition, value and involvement of Indigenous peoples in global evaluation practice and endeavors and,

Promote and Support Indigenous peoples' self-determination of their evaluation agenda. (Bremner \& Were, 2016)

It is time for Indigenous peoples to determine their evaluation agendas. But how do we as evaluators support this endeavour? We need to let Indigenous peoples set and control their own evaluation and research agendas.

While our national organization has taken first steps in attempting to address reconciliation, what can we do as individual evaluators to incorporate reconciliation into our work?

\section{EVALUATORS AS STORYTELLERS}

I believe evaluators are storytellers. When you look at our world today, the following quotation by Ben Okri (1997, p. 46), a Nigerian storyteller, is more relevant than ever:

In a fractured age, when cynicism is god, here is a possible heresy: we live by stories, we also live in them. One way or another we are living the stories planted in us early or along the way, or we are also living the stories we planted-knowingly or unknowingly-in ourselves. We live stories that either give our lives meaning or negate it with meaninglessness. If we change the stories we live by, quite possibly we change our lives.

The importance of storytelling is well documented, and the important elements of culture, including language, customs, spirituality, history, and locality, all add to the stories we have to tell (Chouinard \& Cousins, 2007; Kirkhart, LaFrance, \& Nichols, 2011; Nee-Benham, 2008; Wilson, 2008). A recent article highlighted how Tribal Critical Theory (TCT) recognizes the importance of stories. As TCT suggests, not only are tribal beliefs, philosophies, and customs important for understanding the lived realities of Indigenous peoples, but "it [TCT] also recognizes the importance of story as a legitimate data source and building block of theory and insists that the interconnected nature of theory and practice demands that researchers work towards social change" (Bowman, Francis, \& Tyndall, 2015, p. 338). 
In many cases, we have not told the stories that need to be told. As storytellers we must be aware, when we approach our communities, of the trauma that is still being felt in many communities. As responsible evaluators we need our work to address cultural repression and support cultural renewal. We have to give back the knowledge we have been taking from the communities, and we have to help them become sovereign nations with the power and ability to control their own destinies. As noted by Kirkhart et al. (2011),

Historical trauma must be addressed. Communities need to heal from cultural repression, including repression for which research has been culpable. Evaluation must contribute to learning that supports cultural renewal and revitalization. Selfdetermination must be heard and understood by evaluators as a necessary condition of good evaluation.

\section{THE STORIES WE USUALLY HEAR}

Canadians routinely are presented with information concerning the lifespan of Indigenous adults, which we are told is 15 years shorter than for non-Indigenous adults (CBC, 2018b). We are informed that for Indigenous peoples, the incidence of diseases such as diabetes is four times the rate for non-Indigenous Canadians. Canadians are repeatedly told that there is an overrepresentation of Indigenous peoples when looking at infant mortality, suicide, and incarceration rates. These are the stories that are being told, which, according to Allan and Smylie (2015), are "frequently presented without the context needed to make sense of the information provided." Furthermore, they go on to suggest not only is the context absent, but stories of Indigenous health in Canada also can be "characterized by the presence of racist stereotypes and inaccuracies pervasive in mainstream Canadian narratives."

Another story with which we have become familiar is the number of Indigenous communities in Canada without running water and living under water advisories. As of August 2019, there were 56 long-term (i.e., longer than 12 months) advisories in effect (Indigenous Services Canada, 2019). These stories should "remind us that First Nations, Inuit and Métis peoples' health status reflects the socioeconomic, environmental, and political contexts of their lives, a context inextricable from past and contemporary colonialism" (Greenwood, de Leeuw, \& Lindsay, 2018).

Other stories we hear concern the experiences of Indigenous peoples in the justice system. In Canada there have been a number of high-profile justicerelated cases involving Indigenous victims (CBC, 2018a). The results from these trials have led to questions regarding a justice system seen to be racist. A nonIndigenous male in Winnipeg was found not guilty of killing Tina Fontaine, a 15-year-old Indigenous female. Two weeks earlier, a non-Indigenous male in Saskatchewan, accused of killing Colten Boushie, a 22-year-old Indigenous man, was also found not guilty. These verdicts sparked outrage and were delivered almost a year after the Prime Minister of Canada called for a review of laws and 
policies related to Indigenous peoples (Government of Canada, 2017). One must ask, as did Josée Lavoie, head of the Centre for Aboriginal Health Research at the University of Manitoba, "as a researcher, I wonder how many reports ... we need until we ask for action[?]” (CBC, 2015).

As evaluators, we know there have been many "reliable" and "valid" studies undertaken in Indigenous communities, and in many cases nothing has changed for those communities. Maybe it is time to think beyond reliability and validity and start talking about "authentic" work, work that is meaningful to the communities:

The challenge for future programs and their evaluations is to be part of the transformation and legitimization of knowledge ... issues of reliability and validity can be less important than the political and social realities that surround programs and communities wherein they operate. Equity and social justice should become the touchstones of practice, rather than the handmaidens of "reliability" and "validity." Rigor gives way to authenticity. And regardless of these notions, credibility becomes the servant of audience. (Lee \& Bremner, 2012, p. 66)

Evaluation must build on the communities' cultural, social, and spiritual values and support cultural resurgence. The focus of an Indigenous approach should not be on individuals and independence but on relationships and the community/ collective. We must ask ourselves as evaluators the following questions: Is our work perpetuating contemporary colonialism? Are we doing things in a way that preserves the status quo? What can we do to help ensure that as Indigenous peoples we have the power to set and control our own evaluation and research agendas?

\section{OUR ROLE IN TRUTH AND RECONCILIATION}

When I interviewed a young Indigenous woman who is a leader in her community, we talked about reconciliation. She mentioned that in her community reconciliation is viewed as helping white people feel less guilty about themselves because, while there has been a lot of talk about reconciliation, nothing has changed in her community. A few months later, when talking to a colleague who had just spoken with an Elder, she mentioned that the Elder wanted to know what had happened to the "truth." It was the Truth and Reconciliation Commission, and everyone just talks about reconciliation. The stories we tell and should tell as evaluators must deal with both truth and reconciliation. The historical and current-day impact of colonial policies speaks to the truth. Evaluators must understand the past realities of the communities in which we work and the roles we have played in perpetuating these truths. Through self-reflection and developing our understanding, evaluators will be able to move to reconciliation and a vision for the future in which Indigenous peoples control and develop their own evaluation agendas.

As mentioned earlier, there are 80,000 survivors of residential schools still living and there are stories that still have to be told; there are truths that have to be 
heard. I believe our role as evaluators is to try to make sure not only that we hear those stories but also that these stories are heard by people in power, policymakers and decision makers in government. That is our responsibility in addressing the "truth" part of truth and reconciliation.

In terms of reconciliation, what can we do that will help change these stories so that visions for the future become reality? What can we do differently in our work? What can we change about how we conduct our enquiries? How can we move beyond sharing and return the power to the communities so we can change the larger story? These are the questions we have to ask ourselves. We have to start acting in reciprocal ways, so we are not only taking but also giving back to the communities in which we work.

\section{EVALUATION AND HUMAN AND NATURAL SYSTEMS}

A number of years ago, I was undertaking case studies in Nunavut. As I was talking with one individual, he made this point: "Rocks are living things. Rivers are living things. Ice is a living thing. If we respect them, they will give us what we need to live in harmony with the system .... We need to ensure a place for both world views." Traditionally, evaluators have looked only at human systems. Recently, we have started to talk about evaluation in human and natural systems and how we need to start dealing with both systems in our work.

Evaluators frequently talk about silos, and we hear about silos in government; however, as evaluators we have been undertaking our work in silos. Funders, for the most part, have not funded holistic evaluations. They fund evaluations of individual initiatives - an education initiative or a health initiative or a justice initiative; however, in the communities in which I work, these are interconnected. Sometimes you have to address health and wellness before you can look at education, and sometimes you need to address justice issues before you deal with education. If evaluators continue to work in silos and if funders continue to fund in silos, we will never address some of the issues that need to be resolved. There is a need to move toward a more holistic approach, one that better reflects the relationality of Indigenous world views in which the human and natural systems are one system composed of relationships with the land, culture, community, people, ancestors, and spirituality.

Until recently I believed that Two-Eyed Seeing was a useful metaphor to take the Indigenous ways and meld them with the Western ways: "Two-Eyed Seeing-To see from one eye with the strengths of the Indigenous ways of knowing, and from the other eye with the strengths of the Western ways of knowing, and to use both of these eyes together" (Hatcher, Bartlett, Marshall, \& Marshall, 2009, p. 3). My concern-and it is the same concern I have with co-creation and cultural competency-is that, while they are interesting concepts, they have the potential to maintain contemporary colonialism. My experience with Two-Eyed Seeing is that one eye is always bigger-and it is not the Indigenous eye. We have to give control back to Indigenous people 
and their communities; they must be the ones who control their evaluation and research agendas.

\section{MOVING FORWARD}

The Indigenous peoples of Canada are not a homogeneous group. According to the 2016 Census, Indigenous peoples made up $4.9 \%$ of the total Canadian population. First Nations people, those who are registered or treaty Indians under the Indian Act and those who are not, make up 58\% of the Indigenous population, followed by Métis (35\%) and Inuit (4\%) (Statistics Canada 2017).

Furthermore, there are many First Nations communities in Canada: more than 630, representing more than 50 First Nations, many of which have experienced different political and contextual realities. The Government of Canada estimates there are approximately 50 Indigenous languages in 12 language families, while UNESCO estimates that there are approximately 90 Indigenous languages. Our efforts in reconciliation will need to be as diverse as the populations with whom we are privileged to work.

I was discussing reconciliation with an individual I recently interviewed. We both noted that, in Canada, there have been many ongoing discussions regarding reconciliation at all levels. However, he made the point that this is just the beginning of our journey in reconciliation as a country. He stated that this journey will involve long, hard, difficult discussions; some people will get hurt and upset. However, these are the types of discussions we need as a country—and a profession-as we move forward.

How will the CES initiatives, such as the Essential Skills Series and the E-Institute, address the new competencies? We have a membership category for individuals from the Global South, which is a positive step. Are there changes that CES can make to its membership categories to attract Indigenous practitioners? In doing so, we may need to define evaluators in non-traditional ways; it might be an individual working in an Indigenous community who is a community development officer, it might be an Elder, or the principal of a school in an Indigenous community. These are individuals who are really important for us to welcome into our association and into our work.

These are the questions I am going to be asking myself continuously: How can we ensure that we incorporate truth and reconciliation into our work-my work-into what CES does as an organization? What stories need to be told and who will tell them? How will these stories speak to truth and reconciliation? How can we ensure that these stories will be heard?

As evaluators "we need to see Indigenous peoples as creators of their own destinies and experts in their own realities.... [evaluation as] a source of enrichment to their lives and not a source of depletion or denigration" (Weber-Pillwax, 1999, p. 38). As Justice Murray Sinclair, Chair of the TRC reminds us, "The road we travel is equal in importance to the destination we seek. There are no shortcuts. When it comes to truth and reconciliation, we are all forced to go the distance" (TRC, 2012, p. 1). 


\section{REFERENCES}

Allan, B., \& Smylie, J. (2015). First peoples, second class treatment: The role of racism in the health and well-being of Indigenous peoples in Canada. The Well Living House Action Research Centre for Indigenous Infant, Child, and Family Health and Wellbeing, St. Michael's Hospital. Retrieved from http://www.wellesleyinstitute.com/wp-content/ uploads/2015/02/Summary-First-Peoples-Second-Class-Treatment-Final.pdf

Bowman, N. R., Dodge Francis, C., \& Tyndall, M. (2015). Culturally responsive Indigenous evaluation: A practical approach for evaluating indigenous projects in tribal reservation contexts. In S. Hood, R. Hopson, \& H. Frierson (Eds.), Continuing the journey to reposition culture and cultural content in evaluation theory (pp. 335-359). Charlotte, NC: Information Age.

Bremner, L. K., \& Were, L. (2016). EvalIndigenous concept paper. Retrieved from http:// forum.ioce.net/forum/open-forums/evalindigenous

Canadian Broadcasting Corporation (CBC). (2015). First nations adults more than twice as likely to die from avoidable causes. Retrieved from https://www.cbc.ca/news/indigenous/ first-nations-adults-more-than-twice-as-likely-to-die-from-avoidable-causes-1.31 96496

Canadian Broadcasting Corporation (CBC). (2018a). High-profile court cases highlight difficulties for Indigenous youth, say leaders. Retrieved from https://www.cbc.ca/news/canada/ saskatoon/colten-boushie-tina-fontaine-verdicts-indigenous-youth-1.4549049

Canadian Broadcasting Corporation (CBC). (2018b). Lifespan of Indigenous people 15 years shorter than that of other Canadians, federal documents say. Retrieved from https:// www.cbc.ca/news/health/indigenous-people-live-15-years-less-philpott-briefing1.4500307

Canadian Evaluation Society (CES). (2016a, May 17). The CES takes position regarding reconciliation in Canada. Retrieved from https://evaluationcanada.ca/news/6348

Canadian Evaluation Society (CES). (2016b, June 21). Letter to Carolyn Bennett. Retrieved from https://evaluationcanada.ca/sites/default/files/bennett_carolyn_20160621_ en.png

Canadian Evaluation Society (CES). (n.d.). Competencies for Canadian evaluators. Retrieved from https://evaluationcanada.ca/competencies-canadian-evaluators

Chouinard, J., \& Cousins, B. (2007). Culturally competent evaluation for aboriginal communities: A review of the empirical literature. Journal of MultiDisciplinary Evaluation, 4(8), 40-57.

Government of Canada. (2017). Prime minister announces Working Group of Ministers on the Review of Laws and Policies Related to Indigenous Peoples. Retrieved from https://pm.gc.ca/eng/news/2017/02/22/prime-minister-announces-working-groupministers-review-laws-and-policies-related

Greenwood, M., de Leeuw, S., \& Lindsay, N. (2018). Challenges in health equity for Indigenous peoples in Canada. The Lancet, 391(10131), 1645-1648. Retrieved from https:// www.thelancet.com/journals/lancet/article/PIIS0140-6736(18)30177-6/fulltext

Hatcher, A., Bartlett, C., Marshall, M., \& Marshall, A. (2009). Two-eyed seeing: A crosscultural science journey. Green Teacher, 86, 3-9. 
Indigenous and Northern Affairs Canada. (n.d.). Indian Residential Schools. Retrieved from https://www.aadnc-aandc.gc.ca/eng/1100100015576/1100100015577\#sect1

Indigeousfoundations.arts.ubc.ca. (2009). University of British Columbia. Retrieved from https://indigenousfoundations.arts.ubc.ca/the_residential_school_system/

Indigenous Services Canada. (2019). Ending long-term drinking water advisories. Retrieved from https://www.sac-isc.gc.ca/eng/1506514143353/1533317130660

Kirkhart, K., LaFrance, J., \& Nichols, R. (2011). Improving Indian education through Indigenous evaluation. American Educational Research Association Conference, New Orleans, LA.

Lee, L., \& Bremner, L. (2012). Evaluation frameworks and educational equity: Friends or foes? In D. Pop (Ed.), Education policy and equal education opportunities (pp. 51-68). New York, NY: Open Society Foundations.

Legacy of Hope Foundation. (2014). Forgotten: The Métis residential school experience. Ottawa, ON: Author.

Nee-Benham, M. K. P. A. (Ed.). (2008). Indigenous educational models for contemporary practice: In our mother's voice (Vol. II). New York, NY: Routledge, Taylor and Francis.

Okri, B. (1997). A way of being free. London: Weidenfeld \& Nicolson/Phoenix House.

Statistics Canada. (2017). Aboriginal peoples highlight tables, 2016 Census. Retrieved from https://www12.statcan.gc.ca/census-recensement/2016/dp-pd/hlt-fst/abo-aut/Table. $\mathrm{cfm}$ ? Lang=Eng\& $\mathrm{T}=101 \& \mathrm{~S}=99 \& \mathrm{O}=\mathrm{A}$

Truth and Reconciliation Commission of Canada (TRC). (2012). Interim Report. Retrieved from http://www.trc.ca/assets/pdf/mroom_Interim\%20report\%20English\%20electronic.pdf

Truth and Reconciliation Commission of Canada (TRC). (2015). Honouring the truth, reconciling for the future: Final report of the Truth and Reconciliation Commission of Canada. Retrieved from http://www.trc.ca/assets/pdf/Honouring_the_Truth_Reconciling_for_the_Future_July_23_2015.pdf

Weber-Pillwax, C. (1999). Indigenous research methodology: Exploratory discussion of an elusive subject. Journal of Educational Thought, 33(1), 31-45.

Wilson, S. (2008). Research is ceremony: Indigenous research methods. Winnipeg, MB: Fernwood.

\section{AUTHOR INFORMATION}

Larry Bremner is a former CES national president, CES Fellow, and award winner. He established Proactive Information Services Inc. in 1984 to provide evaluation services to the not-for-profit and public sectors. He has worked across Canada in urban, rural, remote, and Indigenous communities, and throughout Europe. Larry was the driving force behind the creation of EvalPartners' global network EvalIndigenous and was its first chair. Proud of his Métis heritage, he is passionate about equity and access. Larry believes we are compelled to create a future that is inclusive, if we are to address today's crucial social, environmental, and economic issues. 